\title{
Necessity of guidelines for publication of patient-derived cancer models
}

\author{
Tadashi Kondo \\ Division of Rare Cancer Research, National Cancer Center, Chuo-ku, Tokyo, Japan \\ Correspondence to: Tadashi Kondo. Division of Rare Cancer Research, National Cancer Center, 5-1-1 Tsukiji, Chuo-ku, Tokyo 104-0045, Japan. \\ Email: takondo@ncc.go.jp. \\ Provenance and Peer Review: This article was commissioned by the Editorial Office, Annals of Translational Medicine. The article did not undergo \\ external peer review. \\ Comment on: Yu P, Wen J, Wang J, et al. Establishment and characterization of a novel human osteosarcoma cell line for spontaneous pulmonary \\ metastasis research in vivo. Ann Transl Med 2019;7:573.
}

Submitted Nov 23, 2019. Accepted for publication Dec 25, 2019.

doi: 10.21037/atm.2019.12.144

View this article at: http://dx.doi.org/10.21037/atm.2019.12.144

Yu et al. reported the establishment of novel patientderived xenograft (PDX) and cell line (PDC) models of osteosarcomas, and demonstrated that these models can spontaneously metastasize to the lungs (1). Patients with osteosarcomas often suffer from lung metastasis, therefore, the reported models can be useful resources for sarcoma research. Considering the diversity of this disease, models from a single case cannot provide definitive conclusions, and additional models from different cases are needed. In this sense, Yu et al.'s study can be considered an important part of the research community's efforts, and the established models will contribute to research progress, especially if they are shared broadly. Recent comprehensive studies employed a large number of cell lines to integrate data on drug response and genetic information (2-10). Although the number of sarcoma cell lines in these large projects was relatively small, a novel association of mutated cancer genes with cellular responses to drugs was identified in sarcomas (2). Novel cell lines of rare cancers, such as sarcomas, are useful resources for such studies, and the cell line reported by $\mathrm{Yu}$ et al. has the potential to contribute to future sarcoma research (1). However, both the xenograft and cell line reported in their paper have fundamental problems, which are discussed here.

Cell line cross-contamination is a critical issue for the research community. A recent study reported that more than 30,000 scientific publications are based on data produced using misidentified cell lines (11). The incorrect use of cell lines, such as cross-contamination and misidentification, damages the quality and reliability of research, wasting valuable time and money, and every effort should be made to avoid it, no matter how challenging that may be $(12,13)$. Thus, authentication, such as short-tandem repeat (STR) profiling, is generally required for studies using cell lines (14-16). However, Yu et al. did not perform any such cell line authentication. Osteosarcoma has the highest number of cell lines of any of the sarcomas. According to the cell line database, Cellosaurus (17), there are more than 400 osteosarcoma cell lines, which include the original cell lines and their derivatives; many of these are available from public cell banks. Thus, the novel osteosarcoma cell line reported in this article had many opportunities for crosscontamination with existing osteosarcoma cell lines. The authors examined the morphology and expression of certain protein biomarkers in the established cell line (1). However, those data cannot exclude the possibility of cell line crosscontamination. The authors needed to demonstrate the STR data of the original tumor tissues, PDX tissues, and corresponding PDC, to confirm the identification of their models according to current standards for cell line studies. In general, the STR profiles should be pre-requisite data for submission of cell line papers (18). I believe that these concerns are generally shared among scientists who conduct extensive cancer research using cell lines. To guarantee the quality of research amongst the cancer community, the necessity for cell line quality control has long been discussed $(11,12,14-16)$. To combat this issue, many academic journals have set guidelines for cell line authentication 
prior to publication (18). Thus, novel cell lines without authentication data will not be used in future publications, and authors who fail to authenticate their cell lines will lose the opportunity to contribute to research.

In addition, authors should include the clinical and pathological data of the donor patient. These data are relevant to the clinical outcome and decision-making process for the treatment of patients and are common among different models but unique in specific cancers. However, only age, gender, and histological subtype were reported for the case in this paper (1), and it is impossible to evaluate the hypothesis that the characteristics of the reported PDX and PDC were similar to those of the corresponding original tumor. For example, osteosarcomas have distinct characters according to the original site, and it is important to describe from which part of the body the tumor tissue was obtained. The status of pulmonary metastasis of the donor patient is also critical; the authors should have described whether the donor patient had a pulmonary metastasis when the tissue was obtained, when the patient acquired a metastasis, or if the patient did not exhibit metastasis during the observation period. Neoadjuvant chemotherapy, which is a standard treatment for osteosarcomas, should also be mentioned because chemotherapy may affect the nature of the tumor tissue. The genetic and pathologic characterization of the original tumor tissue, which can affect the clinical features of the disease, should also be described. The patient's prognosis after treatment should be described as this information is critical for evaluating the malignant features of the original tumor. These data are particularly important for patientderived cancer models, when the outcomes of in vitro research are used in clinical applications.

I focused on cell lines in these comments. However, what I discussed here should be applied to all types of patientderived cancer models; authentication should be acquired for all models without exception. Clinical and pathological data are unique to specific cancers, but their necessity is common among all models. Although methods for authentication have been established, the necessary clinical and pathological data for patient-derived cancer models have not been incorporated, and guideline committees should include clinicians and pathologists who are certified for individual cancer types. Creating guidelines for clinical and pathological data will require exhaustive efforts, but these guidelines will be indispensable for promoting research productivity and the utility of novel patient-derived cancer models.

\section{Acknowledgments}

Funding: This research was financially supported by the National Cancer Center Research and Development Fund (grant No. 29-A-2).

\section{Footnote}

Conflicts of Interest: The author has no conflicts of interest to declare.

Ethical Statement: The author is accountable for all aspects of the work and ensuring that questions related to the accuracy or integrity of any part of the work are appropriately investigated and resolved.

Open Access Statement: This is an Open Access article distributed in accordance with the Creative Commons Attribution-NonCommercial-NoDerivs 4.0 International License (CC BY-NC-ND 4.0), which permits the noncommercial replication and distribution of the article with the strict proviso that no changes or edits are made and the original work is properly cited (including links to both the formal publication through the relevant DOI and the license). See: https://creativecommons.org/licenses/by-nc-nd/4.0/.

\section{References}

1. Yu P, Wen J, Wang J, et al. Establishment and characterization of a novel human osteosarcoma cell line for spontaneous pulmonary metastasis research in vivo. Ann Transl Med 2019;7:573.

2. Garnett MJ, Edelman EJ, Heidorn SJ, et al. Systematic identification of genomic markers of drug sensitivity in cancer cells. Nature 2012;483:570-5.

3. Barretina J, Caponigro G, Stransky N, et al. The Cancer Cell Line Encyclopedia enables predictive modelling of anticancer drug sensitivity. Nature 2012;483:603-7.

4. Basu A, Bodycombe NE, Cheah JH, et al. An interactive resource to identify cancer genetic and lineage dependencies targeted by small molecules. Cell 2013;154:1151-61.

5. Seashore-Ludlow B, Rees MG, Cheah JH, et al. Harnessing Connectivity in a Large-Scale Small-Molecule Sensitivity Dataset. Cancer Discov 2015;5:1210-23.

6. Boehm JS, Golub TR. An ecosystem of cancer cell line factories to support a cancer dependency map. Nat Rev Genet 2015;16:373-4. 
7. Rees MG, Seashore-Ludlow B, Cheah JH, et al. Correlating chemical sensitivity and basal gene expression reveals mechanism of action. Nat Chem Biol 2016;12:109-16.

8. Haverty PM, Lin E, Tan J, et al. Reproducible pharmacogenomic profiling of cancer cell line panels. Nature 2016;533:333-7.

9. Li H, Ning S, Ghandi M, et al. The landscape of cancer cell line metabolism. Nat Med 2019;25:850-60.

10. Ghandi M, Huang FW, Jane-Valbuena J, et al. Nextgeneration characterization of the Cancer Cell Line Encyclopedia. Nature 2019;569:503-8.

11. Horbach S, Halffman W. The ghosts of HeLa: How cell line misidentification contaminates the scientific literature. PLoS One 2017;12:e0186281.

12. American Type Culture Collection Standards Development Organization Workgroup ASN-0002. Cell line misidentification: the beginning of the end. Nat Rev

Cite this article as: Kondo T. Necessity of guidelines for publication of patient-derived cancer models. Ann Transl Med 2020;8(5):158. doi: 10.21037/atm.2019.12.144
Cancer 2010;10:441-8.

13. Identity crisis. Nature 2009;457:935-6.

14. Almeida JL, Cole KD, Plant AL. Standards for Cell Line Authentication and Beyond. PLoS Biol 2016;14:e1002476.

15. Nims RW, Sykes G, Cottrill K, et al. Short tandem repeat profiling: part of an overall strategy for reducing the frequency of cell misidentification. In Vitro Cell Dev Biol Anim 2010;46:811-9.

16. Masters JR, Thomson JA, Daly-Burns B, et al. Short tandem repeat profiling provides an international reference standard for human cell lines. Proc Natl Acad Sci U S A 2001;98:8012-7.

17. Bairoch A. The Cellosaurus, a Cell-Line Knowledge Resource. J Biomol Tech 2018;29:25-38.

18. Cell Line Authentication Publication Requirements. Available online: https://www.atcc.org/Services/Testing_ Services/Cell_Authentication_Testing_Service/Cell_Line_ Authentication_Publication_Requirements.aspx 